\title{
The Effect of Word of Mouth in Customer Equity and Brand Equity
}

\author{
Guillermo Armelini \\ Universidad de los Andes, Santiago, Chile
}

\begin{abstract}
In this paper the author examines the extent to which word of mouth (WOM) impact on customer equity and brand equity, two of the most popular metrics of marketing productivity. WOM is the most ancient and effective communication tool because its low cost affects the efficiency in the allocation of marketing resources. After an extensive literature review, the author proposes several propositions to be tested in the future concerning how WOM might affect each element of brand equity and customer equity.
\end{abstract}

Keywords: word of mouth, marketing productivity, brand equity, customer equity

\section{Introduction}

Word of mouth (here after WOM) is one of the most ancient and effective mechanisms of communication in the history of human society, and it has been shown as very cost-effective marketing tools (Godes \& Mayzlin, 2004; Hogan, Lemon, \& Libai, 2004; Godes et al., 2005).

Currently, WOM has increased its importance as a communication tool because of two simultaneous reasons. First, there is less interest among consumers in advertising and traditional media. For example, Mckinsey reported that while real spending on prime time television ads has continued to rise, the number of viewers has plummeted $^{1}$. Second, at the same time, WOM's influence has been enhanced by a revolution in information and telecommunication technologies that shortens spatial and temporal distance among individuals. Firms who probably benefit most for such phenomenon are Internet companies. For instance, in a recent interview, Jeff Bezos, CEO of Amazon, said": "We don't do any television advertising, and we take all of the money that we would put into television advertising, and instead put it into things like free Supersaver shipping... That's the philosophy we've taken from the beginning. If you do build a great experience, customers tell each other about that. Word of mouth is very powerful".

"Brick and Mortar" companies are also taking advantage of the process of social contagion among consumers. For example, P\&G launched a word of mouth program called "Vocalpoint" that enrolls moms to talk about its products. The company selects women who have large social networks. They usually receive a steady stream of product samples, and the company allows them to participate in the product design. With a similar strategy Ford promoted its hybrid car: The escape. Many other companies have took advantage of the synergy

Guillermo Armelini, assistant professor of marketing, ESE Business School, Universidad de los Andes.

1 Court, D., Gordon, J., \& Perry, J. (2002). Boosting return on marketing investment. Mckinsey Quaterly.

2 Business Week. (2004, August 2). Jeff Bezos on word of mouth power. 
between advertising and WOM. For example, Unilever launched the Dove "real women, real curves" ad campaign and fostered WOM behavior among its customers, letting women connect online to talk about perceptions of beauty and to express their feelings ${ }^{3}$.

However, WOM might be a "double-edge sword". On the one hand, it has been shown as a powerful marketing tool that might increase firm’s profitability (Arndt, 1967; Day, 1971; Sheth, 1971); On the other hand, when the message is negative, it may cause an even worst damage in companies' financial statement (Richins, 1983; Hogan, Lemon, \& Libai, 2003). For example, the movie Gigli was taken out of screens in the third week after its releases, because of the hard critics that teenagers made and spread out about the movie during the opening week through their cell phones.

Consequently, while advertising effectiveness has been decreasing, and people more and more ask for the advice of a colleague, friends or relatives before buying a product, it is important to understand whether and how WOM effect impact on marketing productivity. The relevance of this issue is grounded in the increasing interest of scholars and managers in how firms can manage (and not only observing) social interactions (Godes et al., 2005) because of the persistence in looking at better and cheaper ways to do marketing.

In this paper, we examine the effect of word of mouth in two models of marketing productivity: customer equity (CE) and brand equity (BE). BE has been widely used to measure marketing effectiveness in settings where customers can not be properly identify (i.e., consumers goods companies where the seller rarely know who is the final customer) (Clark, 1999; Ambler, 2000). Customer equity, on the other hand, is the right approach to assess the allocation of marketing resources when clients can be identified and track over time (either in contractual settings or non-contractual settings) (Bell, Deighton, Reinartz, Rust, \& Swartz, 2002; Rust, Lemon, \& Zeithaml, 2004).

The organization of this paper is the following: In section 2, the author describes the main features of word of mouth that might affect BE and CE. Then the author briefly reviews the selected metrics of marketing productivity and the author proposes several propositions concerning the role of WOM in CE and BE. The paper finishes with a general discussion and conclusions.

\section{Word of Mouth}

WOM is an oral, person-to-person communication between a receiver and a communicator, whom the receiver perceives as non-commercial, regarding a brand, product or service (Arndt, 1967). Research in marketing generally supports the claim that WOM is more influential on behavior than other marketer-controlled sources (Day, 1971; Sheth, 1971; Mahajan, Muller, \& Kerin, 1984). WOM has been shown to influence a variety of conditions: awareness, expectations, perceptions, attitudes, and behavior (Richins \& Root-Shaffer, 1988; Hogan et al., 2004). WOM might be positive or negative, and it happens in the traditional way, in offline and private conversations, or through Internet-based technologies.

\section{Positive and Negative WOM}

A first issue regarding the impact of WOM in CE and BE is the need of distinguishing between the positive and negative effect of WOM.

\footnotetext{
${ }^{3}$ Forrester Research, Integrate word of mouth for lasting success, November 29, 2005
} 
Positive WOM. When there is positive WOM, productivity of marketing is enhanced because word of mouth often complements and extends the effects of advertising (Hogan et al., 2004 ). Sheth (1971) concluded that WOM was more important than advertising in raising awareness of an innovation and in securing the decision to try the product. Day (1971) inferred that this was due to source reliability and the flexibility of interpersonal communication. He computed that WOM was nine times as effective as advertising at converting unfavorable or neutral predisposition into positive attitudes. Consequently, when a positive wage of contagion occurs regarding a certain product, companies usually increase their marketing productivity because positive WOM extends the effects of advertising among actual and future customers, and increases the likelihood that a prospect wants to try the product, without any additional allocation of resources.

Negative WOM. On the other side, when the message is negative, companies should increase their marketing efforts in order to compensate negative WOM. It does appear that negative WOM has a more powerful impact than positive recommendations (Arndt, 1967; Bolfing, 1989; Bone, 1995), meaning that the financial efforts to avoid or compensate negative WOM are proportionally bigger than the savings that companies might get due to positive WOM.

Scholars have debated about whether advertising is the right tool to react against negative WOM or rather another marketing tool should be used to dissipate the harmful effects of this negative message. Mahajan et al. (1984) showed that when there is a negative rumor in the release of a certain product, the most appropriate strategy is to increase and change the level of consumers' awareness through advertising as soon as possible. Other scholars disagree arguing that since dissatisfaction seems to be one of the main sources of negative WOM, advertising is not the right tool to mitigate this effect. Dissatisfaction occurs when the product performance fall bellow consumer's expectations. Richins (1983) showed that there is a relationship between dissatisfaction, complaints and negative WOM. Only with moderate or high level of dissatisfaction, consumers start complaining. If complaints are discouraged, negative WOM effects takes place. In this line, Nyer and Gopinath (2005) demonstrated that facilitating complaining behavior results in reduced levels of negative WOM, because consumers who do complaints experiment a reduction in dissatisfaction whereas those who do not complain engage in negative WOM and committed to their level of dissatisfaction. Consequently, it appears that enabling customer to express themselves leads to reduce the likelihood of negative WOM. Following this logic, it seems that marketing efforts to react against negative WOM should be focused on customer satisfaction to avoid consumers' dissatisfaction which in turn leads to negative WOM.

\section{How and When WOM Is More Likely to Happen?}

Why do people engage in word of mouth communication? An extensive literature review in the field of marketing and sociology suggests that the following factors might influence the likelihood that people try or buy a new product due to the WOM effect:

Similarity or homophily refers to the degree to which individuals are alike in terms of certain attributes. Similarity has been operationalized through the constructs of strong ties (Granovetter, 1973; Brown \& Reingen, 1987). Researchers have shown that people tend to ask for advise or recommendation to closed-related people, such as friends and relatives (Brown \& Reingen, 1987; Bone, 1992). Consequently, the stronger the tie, the more likely people initiate a WOM process. 
Expertise is another important antecedent in WOM. When the expert is the sender, researches have shown that there are some individuals, opinion leaders and market mavens, whose opinion matter more than others (Feick \& Price, 1987; Richins \& Root-Shaffer, 1988; Chan \& Misra, 1990). When potential receivers of WOM look for information, everything equal, they usually ask an expert.

When the expert is the receiver, the degree of expertise can affect not only the purchase decision but also the level of perceived risk. Scholars found that when the receiver is either an "ignorant" or an "expert" in the use of a certain product, it is more unlikely that he/she would actively look for a recommendation (Bansal \& Voyer, 2000). The intuition behind this finding is that experts would decide by themselves because they already have enough knowledge to overcome the risk of the purchasing decision. In the other extreme, completely ignorant individuals do not care about recommendations because they do not have any benchmark of comparison and consequently they usually buy the first thing that they have the opportunity to buy. Consequently, Bansal and Voyer (2000, p. 175) suggested "that there is an inverted U-shaped relationship between knowledge and how actively information is sought”. Individuals which moderate knowledge are the ones who are more likely to ask for advise, and therefore to initiate a WOM process.

Risk perception. Early researches showed that word-of-mouth and opinion leadership functions as an important risk reliever (Ross, 1975). Wangenheim and Bayón (2004, p. 176) characterized risk perception in terms of two categories: social risk, "refers to the negative consequences potentially arising from social environment of the consumer" and financial risk, "refers to the financial loss in case of a 'bad' purchase”. Both social and financial risk perception are the consequence of two kind of interpersonal influence: normative and informational influence. The former arises when an individual attempts to conform to the expectation of others, while the latter operates when individuals accept information as a tool to enhance their knowledge of a certain product or service (Price, Feick, \& Higie, 1989). Consequently, depending on the kind of interpersonal influence, social or financial risk perception will arise, which in turn will condition whom an individual will ask for advise.

Characteristic of the demand. Regarding the influence of the product features in the WOM process, Price et al. (1989) found that in products with high preference heterogeneity, defined as those goods in which consumers tastes have a great variance (restaurant, clothes, etc.), a recommendation about a product is ambiguous because the consumer will need to check whether the pattern that the recommender have used in recommending the product matches his/her own preferences. For that reason, the author argues that in products with high preference heterogeneity a WOM process may happen only when there is a strong tie between the sender and the receiver. However, in goods with low preference heterogeneity (i.e., plumbers and dry machines), since tastes and attitudes have a low variance among consumers, something that worked for a certain individual might also work for another one. In this case, similarity does not play an important role in initiate the WOM process.

Social structure and motivation of the sender. Given that WOM is about interpersonal communications, the social structure where individuals are embedded emerges as a key factor to analyze social contagion. Granovetter (1973) studied the structure of the social network in terms of strong and weak ties. He stressed that information among relatives (strong ties) is redundant and therefore acts as a barrier preventing new ideas from entering the social network. In order to get information flows easily the interaction among "non redundant" contact is needed. These "weak ties", or non redundant contacts, enable innovations to flow from one network to the other. Build on Granoveter's work, Johnson Brown and Reingen (1987) found that at the macro level, weak 
ties displayed an important bridging function, allowing WOM to travel from one distinct subgroup of referral actors to another subgroup, but at the micro level, strong ties were more likely to be activated for the flow of referral information.

Although structure of the social network matters in the study of WOM, the motivation of the sender is another important issue to get the word out. Frenzen and Nakamoto (1993) showed that the likelihood of diffusion through a certain network will depend on the relationship between the strength of ties among the nodes and the value that the sender gives to the information to be transmitted. When information price is greater than the strength of the tie, individuals are not willing to cooperate, hence the contagion process stop before reaching all the members of the network. On the other hand, when the value of the information is cheap, it is more likely that the message would be spread faster through the network.

WOM and the kind of products. While any kind of product might be promoted through informal conversations, certain goods are more likely to be recommended than others. Haywood (1989) argued that WOM is particularly useful for service organizations because they are intangible and non standardized goods, and involve considerable interaction between the customer and the provider. In this regard, Murray (1991) argued that since services are perceived to be riskier than products, and given that the greater the degree of perceived risk in a pre-purchase context, the larger the consumer propensity to seek information about the product, and it is more likely that consumers prefer to seek information from family, friends and peers rather than from sponsored promotional sources when they are consuming services. Beltramini (1989) also found that referrals were the most important source of future clients for professional services.

In the entertainment industry, WOM is a key driver of diffusion. Scholars have shown that the consumer adoption process for movies is very sensitive to word of mouth interactions (Eliashberg, Jonker, Sawhney, \& Wierenga, 2000; Elberse \& Eliashberg, 2003; Dellarocas, Awad, \& Zhang, 2004). TV shows ratings are also sensible to consumers’ informal conversations (Godes \& Mayzlin, 2004).

\section{WOM and Metrics of Marketing Productivity}

In this section, the author analyzes whether and how WOM can enhance the valor of CE and BE. The approach consists of describing each model and suggesting how WOM might affect positively or negatively each variable that integrates them.

\section{Customer Equity}

During the last years, the convergence of unlimited computing power, ubiquitous networks and software that allows capturing a huge amount of customer information, have shift marketing perspective from transaction oriented to customer-based (Bechwati \& Eshghi, 2005). This important shift in marketing perspective demands new metrics for evaluating the most efficient allocation of marketing resources.

Customer equity (CE) and customer lifetime value (CLV) are, in the author's view, the right metrics to assess marketing productivity in customer-centric organizations. CLV is the difference between what it costs to acquire and retain a customer and the revenue generated from him/her over the customer lifecycle (Berger \& Nasr, 1998). Models of CLV basically try to combine the best possible allocation of marketing resources that both minimize the customer acquisition expenditures and maximize customer retention rate. Although the concept implies a simple financial calculation, estimating the net cash flow from a customer can be very 
challenging. These challenges are not only about the calculation of behavioral measures, for example to know what the relation between retention and acquisition should be, but also concerning the relation between unobservable and observable measures (i.e., how satisfaction impact retention rates).

Customer equity (CE) includes the calculation of CLV in the entire customer base. CE is defined as the total of the discounted lifetime values summed over the firm's entire current and future customers (Blattberg \& Deighton, 1996; Rust et al., 2004). Both, customer equity and customer life time value have been used to assess marketing productivity (Reinartz \& Kumar, 2000; Berger, Weinberg, \& Hanna, 2003; Rust et al., 2004; Reinartz, Kumar, \& Thomas, 2005).

In order to analyze the impact of WOM in CLV, and consequently on CE, the author decomposes the analysis in two of the CLV drivers: customer acquisition and customer retention.

Acquisition. In a CLV model, the more customers the firm acquired through WOM, everything else equal, the biggest the value of CLV, because a firm does not need to make a financial effort to acquire customers.

A WOM process can be initiated either by the sender or by the receiver. In the last case, the probability that a prospect would ask for advice and becomes a customer through WOM increases when the demand is featured by low preference heterogeneity, the receiver is neither an expert nor an ignorant and when there is a strong tie between the giver and the receiver. It is also more likely to happen if the receiver needs an advice regarding a service.

If the WOM process is initiated by the giver, it is likely that he/she is already a customer. Several issues concerning customer referral value might impact on CE. First of all, as Kumar and colleagues (2007) indicate, there are customers who are worthy because of their referral value (and not necessarily because of their individual economic value) that is because of their ability to bring in new customers to the firm. Who are they? What are the characteristics of customer with a high referral value? Both are open questions that have not been answered yet. Second and one possible answer to the last question, customer who are opinion leaders tend to be more efficient to bring in new customers to the firm because of their influence (Valente \& Davis, 1999; Iyengar, Van Den Bulte, \& Valente, 2009). The question here is what are the features of opinion leaders that lead them to bring new customers to the firm. In this sense it is important to make a distinction between connectors, those who socially connected to many others, from experts, those who have a expertise in a certain field and are influential to the extent that others ask them for advice. Recent researches show that connectors are highly influential in the process of acquiring new customers (Goldenberg, Han, Lehmann, \& Hong, 2009; Iyengar et al., 2009), while the role of experts is much controversial (Eliashberg \& Shugan, 1997).

Retention. Customer retention is the probability of a customer being "alive” (Gupta \& Zeithaml, 2005). When the focus of analysis is retention, WOM impacts on this constructs as the probability that an existing customer would recommend a company's product during his/her lifetime value, therefore in this section the author analyzes the driver of retention and the likelihood that retained customers initiates a WOM process.

Researchers and practitioners have widely studied the causes of customer retention or customer loyalty, but still there is not a general consensus about its antecedents. Early researches show that high quality products/services create high levels of customer satisfaction. The latter leads to an increment in customer loyalty, which in turn becomes the most important driver of financial performance (Reichheld \& Sasser, 1990; Anderson \& Sullivan, 1993; Reichheld, 1996). However, more recent papers have shown that other variables like trust 
(Garbarino \& Johnson, 1999) and active commitment (Jones \& Sasser, 1996; Verhoef, Franses, \& Hoekstra, 2002; Verhoef, 2003) may mediate the relationship between customer satisfaction and loyalty.

Regarding the antecedents' word of mouth behavior in customer-centric frameworks, scholars have shown that satisfaction (Reingen \& Kernan, 1986; Anderson, 1998; Biyalogorsky, Gerstner, \& Libai, 2001; Ranaweera \& Prabhu, 2003), active commitment (Harrison-Walker, 2001; Verhoef et al., 2002; Brown, Barry, Dacin, \& Gunst, 2005), identification (Brown et al., 2005) and trust (Verhoef et al., 2002; Ranaweera \& Prabhu, 2003) are significant antecedents of WOM. When people are satisfied, committed or trust their supplier, it is more likely that they share their positive feelings with somebody else. However, what is not clear yet is whether loyal customers are more likely to initiate a WOM process. In other words, knowing that loyal customers are individuals with a high level of satisfaction and active commitment, could we infer that those customers would recommend the firm's product to somebody else? And if this is the case, for how long do they do? Reichheld (2003) argued that WOM behavior is a proxy of customer loyalty. Loyal customers are more likely to recommend a product or service than non loyal customers, and they probably behave like this during their entire life as customers (Reichheld \& Sasser, 1990).

However, other scholars disagree, because they found that the age of the relationship is a mediating factor between relational constructs (satisfaction, active commitment) and customer referrals (Verhoef et al., 2002). Besides, Wangenheim and Bayón (2004) showed that customers who usually switch from one supplier to the other, are more likely to engage in WOM than stayers (loyal customers). In addition, those switchers who come from referrals have been shown to be more positive WOM givers. This finding is in line with early researches that show WOM is higher in the period shortly after purchase (Richins \& Root-Shaffer, 1988). The intuition behind this result is that people who are actually satisfied with a new purchasing experience are more likely to tell others about such event, whereas stayers once they have told to all their contacts about the product, they are more unlikely to recommend it.

In summary, WOM might affect CE either in the stage of acquisition or during the customer lifetime. In the first point, opinion leaders (mostly connectors), characteristics of the product and expertise of the receiver make more or less likely the process of WOM. Once the individual becomes a customer, there is debate about whether and for how long customers would get the word out. On the one hand, some scholars argue that referral behavior is a proxy of loyalty. On the other hand, it seems that WOM behavior is more likely to happen among retained customers right after their first purchase and their willingness to recommend would decrease over time. For that reason, we propose the following propositions:

Proposition 1: The more customers with features of connectors the firm has, the larger its CE is.

Proposition 2: Loyal customers tend to recommend the firm's product to others during his/her entire life as customers.

Proposition 3: Loyal customers tend to recommend the firm's product right after their first purchase, decreasing their willingness to recommend over time.

\section{Brand Equity}

Brand equity (BE) is defined as the marketing effects or outcomes that accrue to a product with its brand name compared with those that would accrue if the same product did not have the brand name (Aaker, 1991). Ailawadi et al. (2003) distinguished among three majors approaches to measure BE: (1) financial, to calculate the 
value of brands as an intangible asset, (2) product market outcomes: the benefit of brand equity should be reflected in the brand's performance in the marketplace, and (3) customer mindset measures, that assess relational constructs that customers have towards a brand (awareness, satisfaction, loyalty among others), which ultimately affect brand equity. These approaches have their advantages and disadvantages and none of them have been proved to be superior to the others. In fact, some complementarities might be found among them.

Keller and Lehman (2003) suggested an integrating framework that includes the above mentioned approaches, which they called "brand value chain”. Brand value chain is a sequential process in which marketing programs impact firstly on relational constructs that affect the consumer mindset (awareness, association, knowledge) which in turns might affect brand performance in terms of the likelihood of the brands to charge premium prices, or to get a larger market share. Brand performance might affect subsequently shareholder values because, since brands with high performance are more likely to generate future revenues, their stocks are more likely to have larger valuations (see Figure 1). In other words, brand equity can be assessed from different perspectives, and it has been shown that one approach might be the source of the other. For example, frameworks based on customers' psychological attributes like awareness, attitudes, knowledge and loyalty (Keller, 1993; Aaker, 1996), have the advantage of being rich in that they assess individual's variables that might affect consumer behavior regarding a certain brand, however they are unable to provide a single measure of brand performance. For that reason, they should be complemented with an approach in which a single financial measure could be got, like price premium (Aaker, 1991; Aaker, 1996) or revenue premium (Aliawadi, Lehman, \& Neslin, 2003). Therefore, mixing both approaches lead to understand the value of the brand and the underlying constructs that explain why a certain brand performs better than other. More recent works have also incorporate the three layers of brand equity in a single one (Srinivasan, Chan, \& Dae Ryun, 2005).

WOM and brand equity. To the best of the author's knowledge, the literature that links WOM with BE is almost inexistent. There are few studies that have looked at isolated aspect of brand equity and WOM (Rust et al., 2004).

To study how WOM affects BE, the author's approach consists in incorporate the effect of word of mouth in the "brand value chain" (Keller \& Lehmann, 2003). The author think that WOM might impact basically in the second stage of this model, on so called "consumer mindset", that is the psychological consumer's response to a set of marketing investment (see Figure 1).

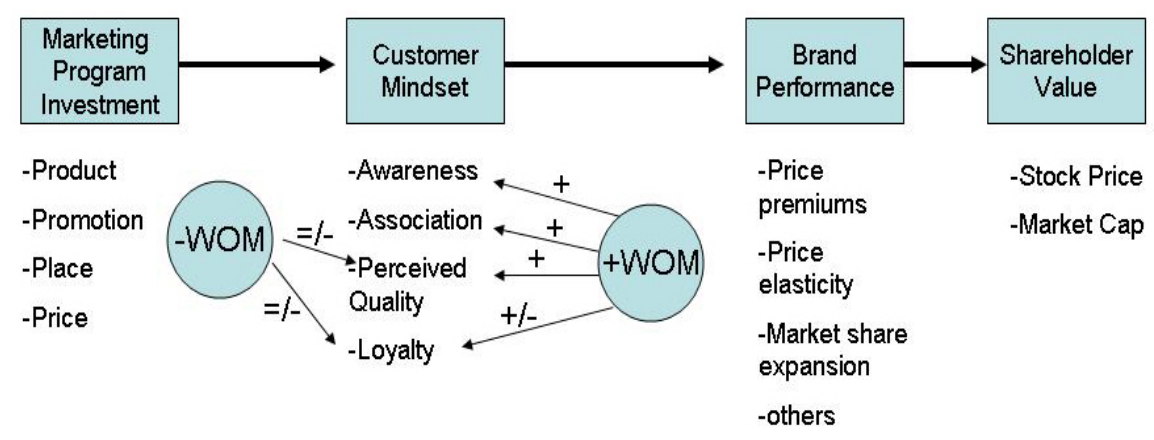

Figure 1. WOM effect on the brand value chain. Adapted from Keller and Lehman (2003). 
A set of different approaches and measures are available to assess brand equity at this stage. Nevertheless, there are four key dimensions that have emerged from previous researches as particular important measures of the customer-mindset: awareness, association, loyalty and perceived quality (Aaker, 1991; Keller, 1993; Ambler et al., 2002). In this section, the author reviews each of them analyzing the effects of word-of-mouth.

Awareness: It is defined as the consumer's ability to identify the brand under different conditions (Keller, 1993). Scholars have shown that positive WOM enhance advertising effect, which in turns increases the level of awareness of a certain product (Day, 1971; Sheth, 1971), therefore positive WOM impacts positively in brand equity through the increment of the level of awareness. Firms like Tremor and Buzz Agent in U.S. and TRND in Europe have developed their business model on the premise of fostering their customers' brand awareness using the idea of "consumer advisory panels", which is based on the fact that if you select the right customers and give them good reasons to talk about your products they will tell to many others, and share their consumption experience with them, thus through this way increasing brand awareness. Consumer advisory panels is a very good example about how WOM is been used by firms to increase their BE.

Brand association: It meanings that a certain brand has for an individual (Keller, 1993). There are three dimensions of brand association: strength (qualitative and quantitative information about the brand), favorability (brand's attributes and benefits that satisfy consumer's needs) and uniqueness (the capacity of a brand to have a unique selling proposition). Herr, Kardes and Kim (1991) showed that positive WOM might enhance the strength of brand association, since information presented in a face to face manner is more credible than information offered in a less vivid manner. However, favorability and uniqueness are two constructs in which the influence of WOM is much more difficult to prove. On the one hand, it seems to be that a recommendation might increase the favorability of a certain brand because since trust has been shown as an antecedent of WOM (Ranaweera \& Prabhu, 2003), it is likely that if an individual strongly recommends a brand to another one, the receiver would pay more attention to this brand. On the other hand, since favorability is an individual perception, because the brand should satisfy the consumer's specific needs, it is not clear whether the effect of WOM would be enough to make the previous brand, the favorite of the receiver. More research is necessary to clarify this relation.

Perceived quality: It is an important dimension of brand equity that refers to the subjective perception that a certain individual has regarding the attributes of a brand (Aaker, 1991). Perceived quality has been shown to be associated with price premiums, price elasticity and brand usage (Aaker, 1996). WOM can influence actual and delayed product judgments, positively or negatively. In the latter researches demonstrated that WOM may damage brand's name when consumer faces a disconfirming experience (Herr et al., 1991; Bone, 1995). However, the strength of the brand's name has also been shown as a reliever of negative WOM (Laczniak, DeCarlo, \& Ramaswami, 2001). Consequently, while WOM might influence perceived quality positively or negatively, in the last case the effect will be reduced by the strength of the brand.

Loyalty: While the author has noticed that loyal customers tend to recommend firm's product during the early stage of their relation with the firm, and their willingness to recommend decrease over time, research has also shown that WOM might enhance brand strength. Muniz and O’Guinn (2001, p. 1) introduced the idea of "Brand Community", which is a "specialized, non-geographically bound community, based on a structured set of social relations among admirers of a brand”. In these communities (i.e., Apple, Harley Davidson), members enhance the value of the brand through social interaction, recommendations and rituals. When the brand is able to create 
belongingness among its customers, they become referrals and they build communities; therefore, through these mechanisms, loyal customers sustain and strengthen the brand. Using this line of thought, Reicheld (2003) proposed Net Promoter Score (NPS) as a metric of brand loyalty based on the score of customers' recommendation. The idea is pretty simple, if a customer consistently recommends a firm (or one of its products) is because he/she would be delighted with the focal firm's value proposition and therefore he/she will be loyal to this firm/brand. Thus, under this model assumption, recommendation is a proxy of customer loyalty. NPS has been widely adopted as both a measure of loyalty and willingness to recommend. However, from an academic perspective scholars have argued against its academic foundations (Keiningham, Cooil, Andreassen, \& Aksoy, 2007).

As it can be seen in Figure 1, WOM affects brand equity in the second stage of the brand value chain. Positive WOM enhances awareness, perceived value, brand association and loyalty. On the other side, negative WOM affects mostly two constructs: perceived value and loyalty. In both cases, when the brand is not strong enough, the negative message may damage brand's name, and consequently its strength, however if the brand is already established its strength reduces the effect of negative WOM. In conclusion positive WOM augments brand equity enhancing the relational constructs that affect consumer's mindset (second stage of the value chain). When there are negative messages against the brand, its strength works as "an umbrella" to reduce the effect of negative WOM, therefore the author proposes:

Proposition 4: Positive WOM increments brand equity increasing the level of brand awareness, improving perceived quality and associations and fostering loyalty through consumers' communities.

Proposition 5: Negative WOM decreases brand equity by diminish perceived quality and the level of brand's loyalty.

Proposition 6: A brand's strength reduces the impact of negative WOM.

\section{Discussion and Conclusions}

Nowadays, firms are facing two simultaneous phenomena that might impact in the effectiveness of their marketing resources. On the one hand, WOM has become a powerful tool due to the increment in the direct communications between pairs. On the other hand, advertising in mass media has been questioned because the number of viewers of TV and readers of newspapers had plummeted. In this context the challenge of measuring WOM has more importance and the author thinks the right way to do that is by introducing its effect on marketing productivity models.

In this paper, the author examines the extent to which WOM affect two of the most popular metrics of marketing productivity: $\mathrm{CE}$ and $\mathrm{BE}$. In the first case, it is interesting to understand how and for how long customers would recommend the firm's product, to understand whether connectors or experts are the right influentials to target in order to get new customers by referrals and how loyal customers behave concerning to their willingness to get the word out. The author also surveys the literature to understand whether and how WOM can impact on BE. Building on Lehman and Keller (2003) framework, the author analyzed how WOM affect the "consumer-mindset" stage of this model. The author concludes that while the effect in brand awareness might be significant, future research should check the extent to which WOM affect brand loyalty and brand association, two construct that are critical in BE. 


\section{References}

Aaker, D. A. (1991). Managing brand equity. Free Press.

Aaker, D. A. (1996). Measuring brand equity across products and markets. Harvard Business Review, 38(3), 18.

Aliawadi, K. L., Lehman, D. R., \& Neslin, S. A. (2003, October). Revenue premium as an outcome measure of Brand Equity. Journal of Marketing, 67, 1-17.

Ambler, T. (2000). Marketing and the bottom line. London (U.K.): Financial Times Prentice Hall.

Ambler, T., Bhattacharya, C. B., Edell, J., Keller, K. L., Lemon, K. N., \& Mittal, V. (2002). Relating brand and customer perspectives on marketing management. Journal of Service Research, 5(1), 13.

Anderson, E. W. (1998). Customer satisfaction and word of mouth. Journal of Service Research, 1(1), 5-17.

Anderson, E. W., \& Sullivan, M. W. (1993). The antecedents and consequences of customer satisfaction for firms. Marketing Science, 12(2), 125-143.

Arndt, J. (1967). Role of product-related conversations in the diffusion of a new product. Journal of Marketing Research, 4(3), 291-295.

Bansal, H. S., \& Voyer, P. A. (2000). Word-of-mouth processes within a service purchase. Decision context. Journal of Service Research, 3(2), 166-177.

Bechwati, N. N., \& Eshghi, A. (2005). Customer lifetime value analysis: Challenges and words of caution. Marketing Management Journal, 15(2), 87-97.

Bell, D., Deighton, J., Reinartz, W., Rust, R., \& Swartz, G. (2002). Seven barriers to customer equity management. Journal of Services Research, 5(1), 12.

Beltramini, R. F. (1989). Professional services referrals: A model of information acquisition. Journal of Services Marketing, 3(1), 35.

Berger, P. D., \& Nasr, N. (1998). Customer lifetime value: Marketing models and applications. Journal of Interactive Marketing Winter 98, 12(1), 14.

Berger, P. D., Weinberg, B., \& Hanna, R. C. (2003). Customer lifetime value determination and strategic implications for a cruise-ship company. Journal of Database Marketing \& Customer Strategy Management, 11(1), 13.

Biyalogorsky, E., Gerstner, E., \& Libai, B. (2001). Customer referral management: Optimal reward programs. Marketing Science 20(1), 82-95.

Blattberg, R. C., \& Deighton, J. (1996). Manage marketing by the customer equity test. Harvard Business Review, 74(4), 136.

Bolfing, C. P. (1989). How do customers express dissatisfaction and what can service marketers do about it? Journal of Services Marketing, 3(2), 5.

Bone, F. P. (1992). Determinants of word-of-mouth communications during product consumption. Advances in Consumer Research, 19(1), 579.

Bone, F. P. (1995). Word-of-mouth effects on short-term and long-term product judgments. Journal of Business Research, 32(3), 213-223.

Brown, J. J., \& Reingen, P. H. (1987). Social ties and word-of-mouth referral behavior. Journal of Consumer Research, 14(3), 350.

Brown, T. J., Barry, T. E., Dacin, P. A., \& Gunst, R. F. (2005). Spreading the word: Investigating antecedents of consumers' positive word-of-mouth intentions and behaviors in a retailing context. Journal of the Academy of Marketing Science, 33(2), 123-138.

Chan, K. K., \& Misra, S. (1990). Characteristics of the opinion leader: A new dimension. Journal of Advertising, $19(3), 53$.

Clark, B. H. (1999). Marketing performance measures: History and interrelationships. Journal of Marketing Management, 15(8), 22.

Day, G. S. (1971). Attitude change, media and word of mouth. Journal of Advertising Research, 11(6), 31-40.

Dellarocas, C., Awad, N. F., \& Zhang, X. (2004). Exploring the value of online reviews to organizations: Implications for revenue forecasting and planning. MIT Working Paper.

Elberse, A., \& Eliashberg, J. (2003). Demand and supply dynamics for sequentially released products in international markets: The case of motion pictures. Marketing Science, 22(3), 329-354.

Eliashberg, J., \& Shugan, S. M. (1997). Film critics: Influencers or predictors? Journal of Marketing, 61(2), 68-78.

Eliashberg, J., Jonker, J. J., Sawhney, M. S., \& Wierenga, B. (2000). MOVIEMOD: An implementable decision-support system for prerelease market evaluation of motion pictures. Marketing Science, 19(3), 226-243.

Feick, L. F., \& Price, L. L. (1987). The market maven: A diffuser of marketplace information. Journal of Marketing, 51(1).

Frenzen, J., \& Nakamoto, K. (1993). Structure, cooperation, and the flow of market information. Journal of Consumer Research, 20(1), 14.

Garbarino, E., \& Johnson, M. S. (1999). The different roles of satisfaction, trust, and commitment in customer relationships. Journal of Marketing, 63(2), 70-87.

Godes, D., \& Mayzlin, D. (2004a). Firm-created word-of-mouth communication: A field-base quasi-experiment (HBS Marketing Research Paper No. 04-03).

Godes, D., \& Mayzlin, D. (2004b). Using online conversations to study word of mouth communication. Marketing Science, 23(4), 15.

Godes, D. et al. (2005). The firm's management of social interactions. Marketing Letters, 16(3/4), 415-428. 
Goldenberg, J., Han, S., Lehmann, D. R., \& Hong, J. W. (2009). The role of hubs in the adoption process. Journal of Marketing, 73(2), 1-13.

Granovetter, M. (1973). The strength of weak ties. The American Journal of Sociology, 78(6), 20.

Gupta, S., \& Zeithaml, V. (2005). Customer metrics: The past, the present, and the future in academia and practice. Marketing Science Institute (Special Report 05-200, 36).

Harrison-Walker, L. J. (2001). The measurement of word of mouth communication and an investigation of service quality and customer commitment as potential antecedents. Journal of Service Research, 4(1), 60.

Haywood, K. M. (1989). Managing word of mouth communications. Journal of Services Marketing, 3(2), 55.

Herr, P. M., Kardes, F. R., \& Kim, J. (1991). Effects of word-of-mouth and product-attribute information of persuasion: An accessibility-diagnosticity perspective. Journal of Consumer Research, 17(4), 454.

Hogan, J. E., Lemon, K. N., \& Libai, B. (2003). What is the true value of a lost customer? Journal of Service Research, 5(3), 196.

Hogan, J. E., Lemon, K. N., \& Libai, B. (2004). Quantifying the ripple: Word-of-mouth and advertising effectiveness. Journal of Advertising Research, 44(3), 271-280.

Iyengar, R., C. Van Den, B., \& Valente, T. (2009). Opinion leadership and social contagion in new product diffusion (MSI Reports 08-004).

Jones, T. O., \& Sasser, J. W. E. (1996). Why satisfied customers defect. Journal of Management in Engineering, $12(6), 11$.

Keiningham, T. L., Cooil, B. T., Andreassen, W., \& Aksoy, L. (2007). A longitudinal examination of net promoter and firm revenue growth. Journal of Marketing, 71(3), 39-51.

Keller, K. L. (1993). Conceptualizing, measuring, managing customer-based brand equity. Journal of Marketing, 57(1), 1.

Keller, K. L., \& Lehmann, D. R. (2003). How do brands create value? Marketing Management, 12(3), 26-31.

Kumar, V., Petersen, A. J., \& Leone, R. P. (2007, October). How valuable is word of mouth? Harvard Business Review.

Laczniak, R. N., DeCarlo, T. E., \& Ramaswami, S. N. (2001). Consumers' responses to negative word-of-mouth communication: An attribution theory perspective. Journal of Consumer Psychology, 11(1), 57-73.

Mahajan, V., Muller, E., \& Kerin, R. A. (1984). Introduction strategy for new products with positive and negative word-of-mouth. Management Science, 30(12), 1389-1404.

Muniz Jr, A. M., \& O’Guinn, T. C. (2001). Brand community. Journal of Consumer Research, 27(4), 412.

Murray, K. B. (1991). A test of services marketing theory: Consumer information acquisition activities. Journal of Marketing, 55(1), 10.

Nyer, P. U., \& Gopinath, M. (2005). Effects of complaining versus negative word of mouth on subsequent changes in satisfaction: The role of public commitment. Psychology \& Marketing, 22(12), 937-953.

Price, L. L., Feick, L. F., \& Higie, R. A. (1989). Preference heterogeneity and coorientation as determinant of perceived informational influence. Journal of Business Research, 19, 227-242.

Ranaweera, C., \& Prabhu, J. (2003). On the relative importance of customer satisfaction and trust as determinants of customer retention and positive word of mouth. Journal of Targeting, Measurement \& Analysis for Marketing, 12(1), 82-90.

Reichheld, F. F. (1996). The loyalty effect-The hidden force behind growth, profits and lasting value. Boston: Harvard Business School Press.

Reichheld, F. F. (2003). The one number you need to grow. Harvard Business Review, 81(12), 46 -54.

Reichheld, F. F., \& Sasser, J. W. E. (1990). Zero defections: Quality comes to services. Harvard Business Review, 68(5), 105.

Reinartz, W. J., \& Kumar, V. (2000). On the profitability of long-life customers in a noncontractual setting: An empirical investigation and implications for marketing. Journal of Marketing, 64, 19.

Reinartz, W. J., Kumar, V., \& Thomas, J. S. (2005). Balancing acquisition and retention resources to maximize customer profitability. Journal of Marketing, 69, 13.

Reingen, P. H., \& Kernan, J. B. (1986). Analysis of referral networks in marketing: Methods and illustration. Journal of Marketing Research (JMR), 23(4), 370-378.

Richins, M. L. (1983). Negative word-of-mouth by dissatisfied consumers: A pilot study. Journal of Marketing, 47(1).

Richins, M. L., \& Root-Shaffer, T. (1988). The role of involvement and opinion leadership in consumer word-of-mouth: An implicit model made explicit. Advances in Consumer Research, 15(1), 32-36.

Ross, I. (1975). Perceived risk and consumer behavior. A critical review. Advances in Consumer Research, 2(1), 19.

Rust, R., Lemon, K., \& Zeithaml, V. (2004, January). Return on marketing: Using customer equity to focus marketing strategy. Journal of Marketing, 68, 18.

Sheth, J. N. (1971). Word-of-mouth in low-risk innovations. Journal of Advertising Research, 11(3), 15-18.

Srinivasan, V., Chan, S. P., \& Dae Ryun, C. (2005). An approach to the measurement, analysis, and prediction of brand equity and its sources. Management Science, 51(9), 1433-1448.

Valente, T., \& Davis, R. L. (1999, November). Accelerating the diffusion of innovations using opinion leaders. ANNALS, 566.

Verhoef, P. C. (2003). Understanding the effect of customer relationship management efforts on customer retention and customer share development. Journal of Marketing, 67(4), 30-45.

Verhoef, P. C., Franses, P. H., \& Hoekstra, J. C. (2002). The effect of relational constructs on customer referrals and number of services purchased from a multiservice provider: Does age of relationship matter? Journal of the Academy of Marketing Science, 30(3), 202-216.

Wangenheim, F., \& Bayon, T. (2004). The effect of word of mouth on services switching. Measurement and moderating variables. European Journal of Marketing, 38(9/10), 1173-1185. 